Article

\title{
A Water Balance Budget for Bung Boraphet-A Flood Plain Wetland-Reservoir Complex in Thailand
}

\author{
Nutchanart Sriwongsitanon *, Kritsanat Surakit and Peter R. Hawkins \\ Department of Water Resources Engineering, Kasetsart University, 50 Paholyothin Rd, Ladyao, \\ Jatujak, Bangkok 10900, Thailand \\ * Author to whom correspondence should be addressed; E-Mail: fengnns@ku.ac.th; \\ Tel.: +66 2 5791567; Fax: +66 25791567.
}

Received: 12 October 2009; in revised form: 26 November 2009 / Accepted: 26 November 2009 / Published: 30 November 2009

\begin{abstract}
A water balance model was developed for Bung Boraphet reservoir, a large flood plain lake in Thailand, from daily measurements over three inflow outflow cycles between 2003 and 2006. Measurement error was 10\% (as one standard deviation) of the total measured volume. The specific yield from the Bung Boraphet catchment was $3.9 \mathrm{~m}^{3} / \mathrm{ha} / \mathrm{yr}$ and surface water inflow from the local catchment was the largest gain term and evaporation was the largest loss term in the water budget. Irrigation was the second largest loss term and dry season demand exceeded the storage supply. Uncontrolled extraction of water for irrigation is regarded as a threat to the reservoir fishery, although the increasing drawdown range may benefit wetland biodiversity. Sustainable management of the Bung Boraphet wetland will depend on careful management based on an informed understanding of the ecohydrological requirements of all wetland uses. Water balance models like this one are recommended as a tool to allocate water equitably and in ways which can be integrated across the Chao Phraya basin.
\end{abstract}

Keywords: Bung Boraphet; water budget; floodplain reservoir; irrigation demand 


\section{Introduction}

Wetlands are diverse and productive ecosystems that provide numerous resources for human use. All wetlands depend on specific hydrologic conditions for maintenance, but tropical wetland/shallow reservoir systems are especially sensitive to change in water balance as the important physical, chemical and biological processes are all accelerated by higher ambient temperatures [1].

Bung Boraphet is the largest shallow reservoir and wetland complex in Thailand. It is situated at the head of Chao Phraya River flood plain in central Thailand (Figure 1). The human population living around Bung Boraphet uses the reservoir-wetland for rice cultivation and fishing. Other recognised values of the wetland are tourism and biodiversity [2].

Figure 1. Location, dry season catchment and instrumentation for Bung Boraphet study (dashed line delineates the Conservation Zone around Bung Boraphet).

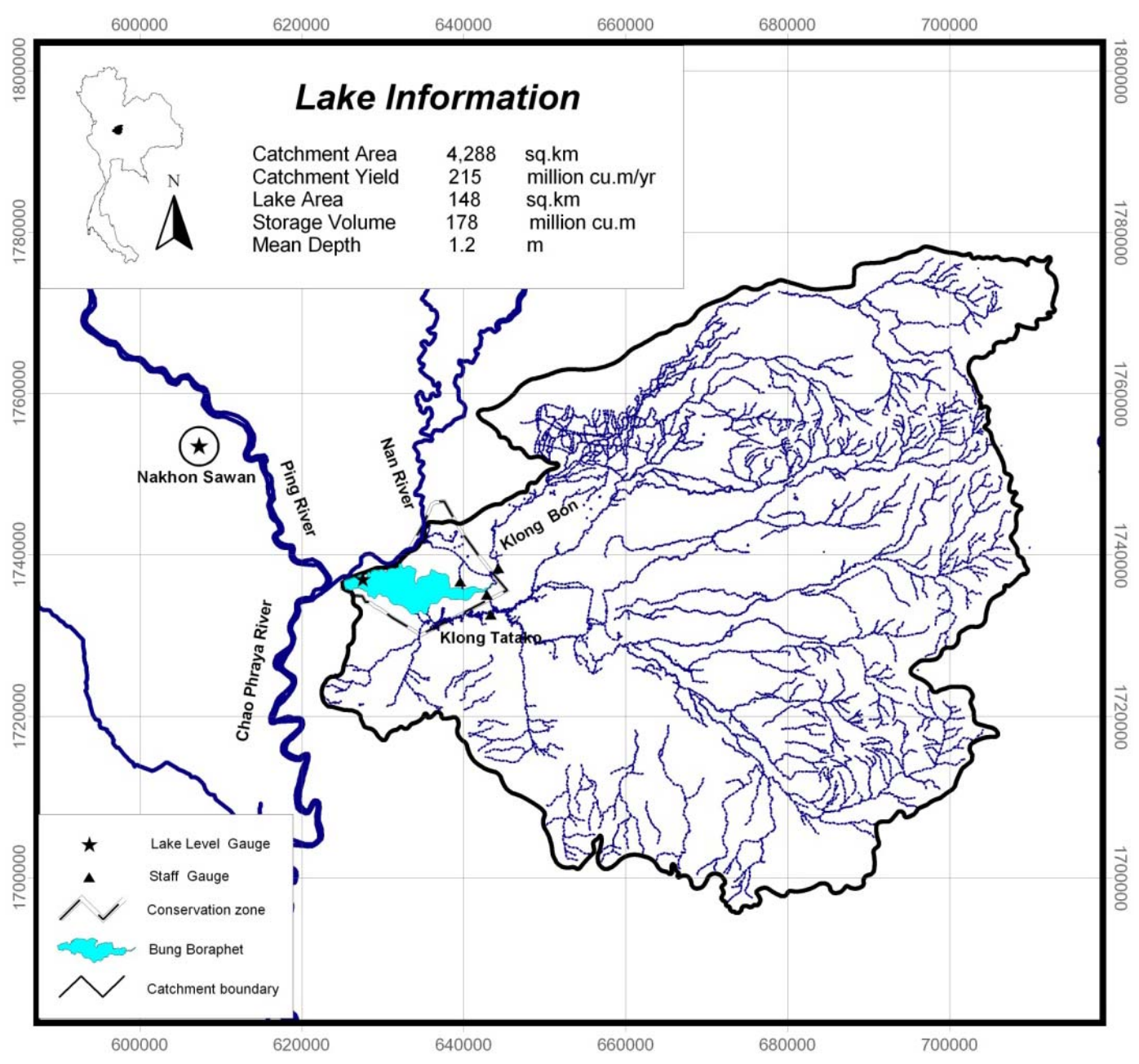

The Bung Boraphet wetland has a long history of active water management. King Rama VII assigned the management responsibility to the Thai Fisheries Department in 1927, when a weir was constructed at the outlet of the wetland to expand the open water fish habitat. In 1937 , a $212 \mathrm{~km}^{2}$ 'Conservation Zone' was gazetted to preserve the wetland habitat from encroachment by settlers. Nevertheless, by 2006, around 30,000 people lived within the Conservation Zone and more than 60\% of the area was under cultivation [3]. 
In response to increasing demand for storage for dry season irrigation supply water, the weir crest was raised to $+23.8 \mathrm{~m}$ (MSL) in 1970's and again to $+24.0 \mathrm{~m}$ (MSL) in 1993. The area of irrigated rice paddy within the Conservation Zone doubled between 1993 and 2003 (to $76 \mathrm{~km}^{2}$ ) [4]. Despite increased storage capacity, the average annual drawdown of the storage has increased, from $77 \%$ between 1993 and 2001, to 91\% between 2002 and 2006 [3].

The developments in the Bung Boraphet catchment reflect an expansion in dry season rice cultivation that has occurred elsewhere in the middle Chao Phraya River basin. This particularly affects the availability of water resources in the dry season (January to June), when the basin undergoes seasonal closure [5]. Dry season water scarcity is predicted to increase in future [6].

Thailand has a long cultural tradition of irrigated rice cultivation, centered on the flood plain of the Chao Phraya River. Historical water resource development was based on the concept that Thais were a nation of rice-growers and thus provision of irrigation infrastructure was the best development option in rural areas [7]. This traditional view has encouraged Thai decision makers to focus on the benefits, rather than the cost/benefit ratios, when considering further irrigation infrastructure development [8]. The continuing demand for irrigation water from Bung Boraphet has prompted new proposals to increase the yield of the storage by raising the weir height [9] or by increasing the rate of diversion from the Nan River [10].

This paper describes the development of a reservoir water budget model for Bung Boraphet, which we propose as an essential tool for hydrological management of the lake-wetland system to sustain the fishery, the biodiversity and the developing tourist industry as well as cultivation of rice.

Simple hydrologic models have been used extensively to describe water balance in wetlands (e.g., $[11,12]$ and shallow flood plain lakes $[13,14])$. The Bung Boraphet system is more complex because of reverse flows from reservoir to catchment in the dry season.

Our aims in developing the water balance model were to 1) quantify the components of the Bung Boraphet water budget seasonally and over the annual inflow outflow cycle; 2) identify the uncertainty associated with the estimate of each component; and 3) to provide a hydrological basis for more equitable and sustainable management of the wetland complex.

\section{Materials and methods}

\subsection{The setting}

Bung Boraphet is situated in Central Thailand, between latitude $15^{\circ} 40^{\prime} \mathrm{N}(1732407 \mathrm{~N})$ and $15^{\circ} 45^{\prime} \mathrm{N}$ $(1741767 \mathrm{~N})$ and longitude $100^{\circ} 10^{\prime} \mathrm{E}(625350 \mathrm{E})$ and $100^{\circ} 23^{\prime} \mathrm{E}(648260 \mathrm{E})$ on the floodplain of the Chao Phraya River just below the confluence of the Ping and Nan Rivers (Figures 1 and 2).

In very wet years, major flood events in the Chao Phraya River system submerge the reservoir and a large area of the Bung Boraphet catchment. These events are less frequent since the construction of the Bhumibol and Sirikit Dams in 1964 and 1974, which have considerably augmented low flows and greatly decreased the frequency of very high discharge events in the Chao Phraya River [15]. However, a major Chao Phraya River flood preceded this study in 2002.

In this study we delineated a dry season Bung Boraphet catchment area of approximately $4,300 \mathrm{~km}^{2}$ from topographic survey maps. Two major streams, Klong Tatako and K. Bon, drain the catchment 
(Figure 1). Other drainage features were two irrigation canals constructed to permit farmers to extract water from Bung Boraphet.

Agriculture is the dominant landuse, occupying $3,730 \mathrm{~km}^{2}(87 \%)$ of the catchment. There are still some areas of natural forest (5\% of catchment) mostly in the conservation zone of the Bung Boraphet wetland [3].

Figure 2. Conceptual model of the water budget for Bung Boraphet.
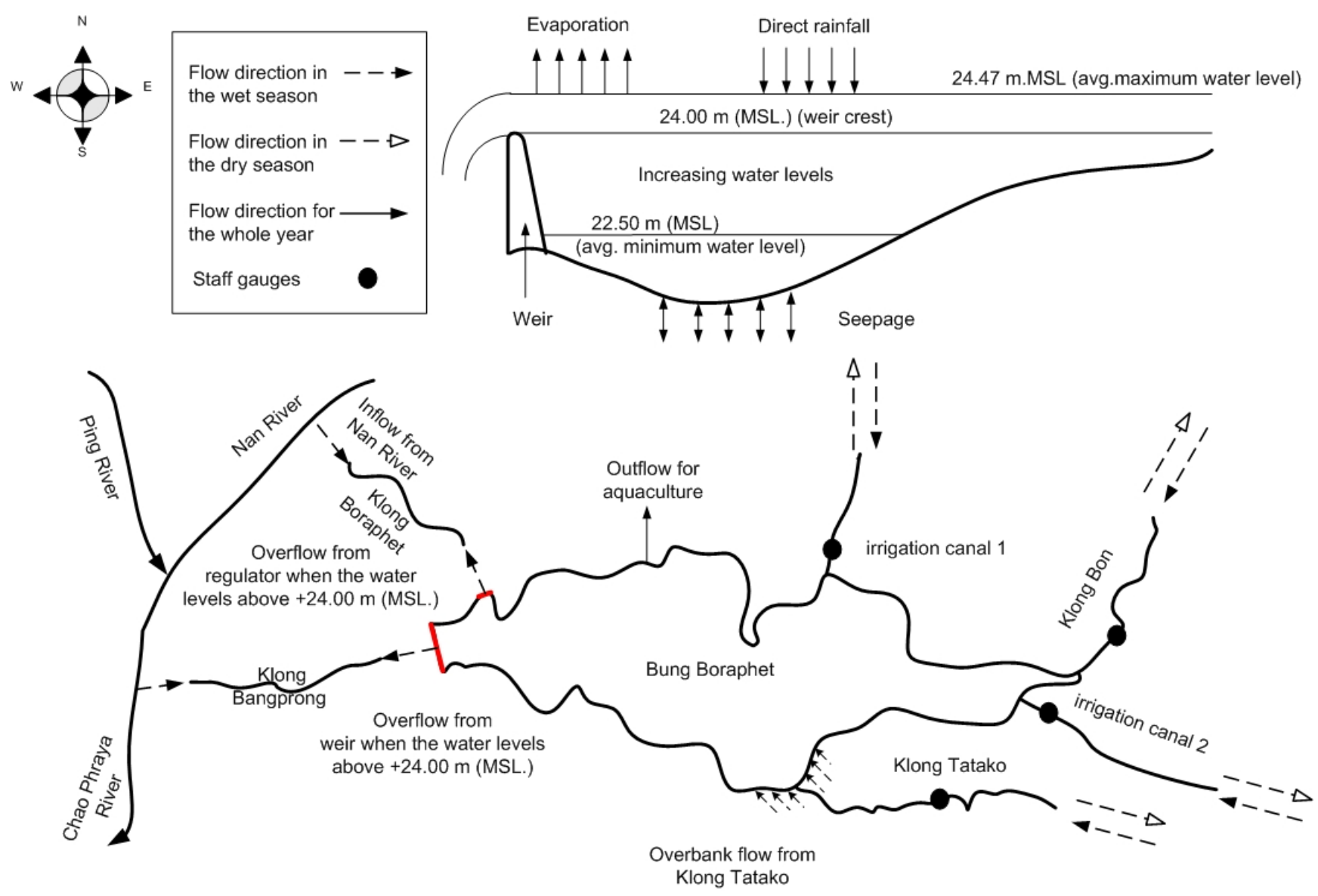

Paddy rice is cultivated intensively in the Bung Boraphet catchment and especially within the conservation zone, where farmers have encroached onto the wetland and use reservoir water to irrigate one or two dry season rice crops per year. This land is particularly susceptible to wet season flooding, so these farmers rely on successful irrigated crops for their livelihood. The area of irrigated paddy within the conservation zone increased from 36 to $76 \mathrm{~km}^{2}$ over 10 years from 1993-2003 [4].

\subsection{Modeling the water budget}

Hydrologic models of lakes and reservoirs that gain or lose water through multiple sources typically decompose the sources into individual components. The model can be calibrated and validated by comparing the predicted net gain or loss against the observed change in the stored volume over the same time period. The mass-balance equation used to estimate the water budget for Bung Boraphet is defined in equation 1 : 


$$
\frac{\Delta S}{\Delta t}=\sum I s(t)-\sum O s(t)+\left(I_{r}-E T\right) A_{s}+e
$$

where $\Delta \mathrm{S}$ is the change in the stored water volume; $\Delta \mathrm{t}$ is the time interval (daily);

$\sum I s(t)$ is the total surface water inflow; $\sum O s(t)$ is the total surface water outflow;

$I_{r}$ is the rainfall onto the reservoir;

$E T$ is the evaporation from the reservoir surface;

$A_{S}$ is the surface area of the reservoir computed from the water level; and

$e$ is a residual error term representing contributions from ungauged watersheds, seepage, other extractive uses like aquaculture, and method and measurement errors.

Conceptual model and calculation methodology

The surface water flow pattern in the Bung Boraphet catchment was unusual because in the dry season, flow in the streams and irrigation canals close to the lake reversed, when farmers upstream pumped water for irrigation. These extractions drew down the lake storage. A conceptual model of the Bung Boraphet water budget (Figure 2) illustrates these seasonal changes in direction of water flow. The methodology used to calculate the main components of the budget is explained in Figure 3.

Figure 3. Process model for calculating the daily water budget for Bung Boraphet.

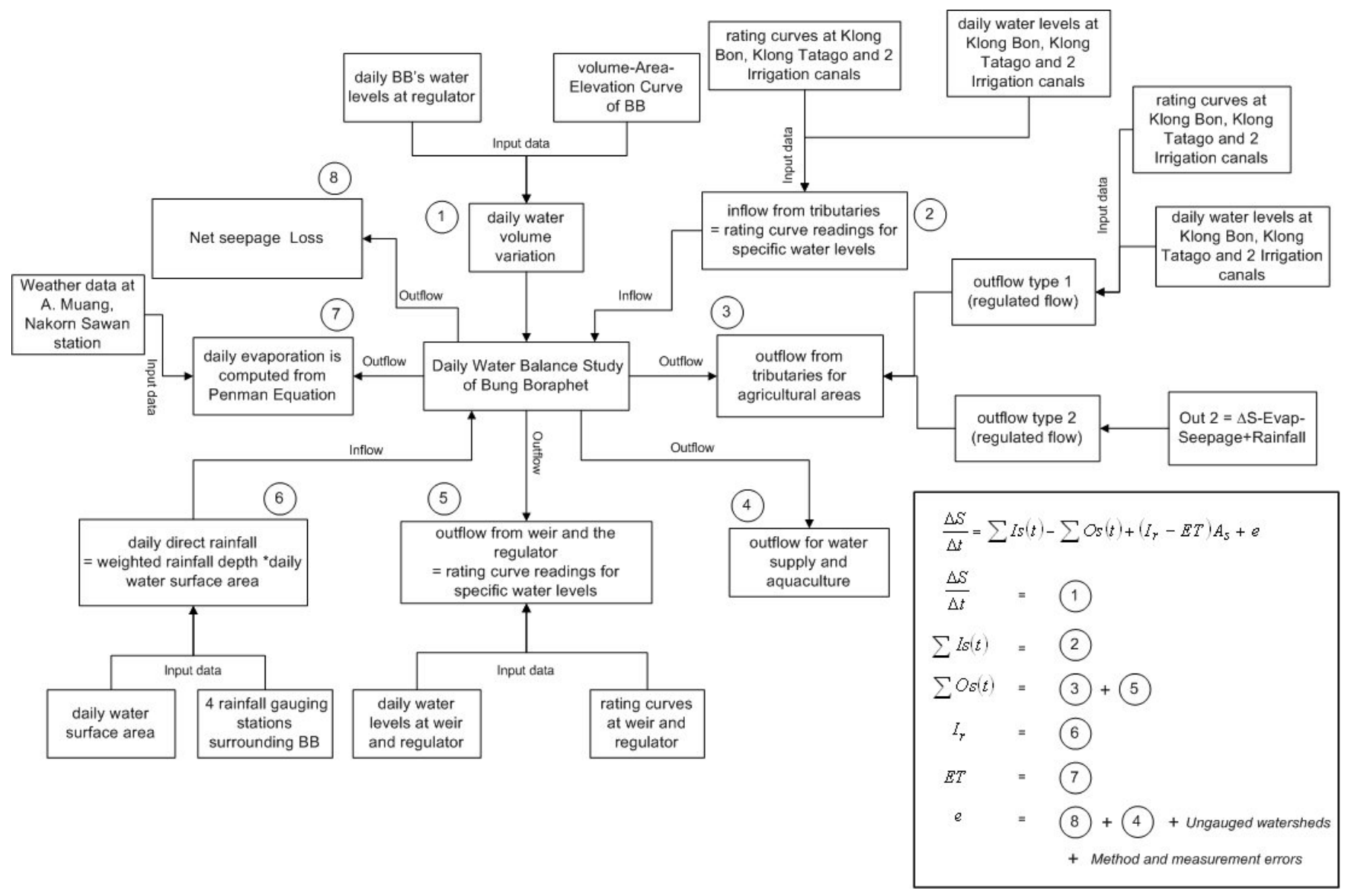




\subsection{Components of the water budget}

The hydrology of the Bung Boraphet system is governed by a monsoonal climatic regime and is highly seasonal. We divided each annual hydrological cycle into inflow and outflow periods determined by the trend in the change in reservoir water level and the direction of water flow in the catchment streams. An annual cycle commenced when the reservoir level started to rise was the minimum of the previous year and ended on the minimum of that year.

Observational data on all components were collected over more than three complete cycles, from December 2002 until April 2006. We then estimated the contributions of each term in the water balance to each flow period within each complete annual water cycle. This approach was a better estimate of the resource use than an account based on the Thai water year (1 April and 31 March).

\subsubsection{Surface water flows ( $\Sigma$ Is and $\Sigma O \mathrm{Os})$}

Surface water flowed into the reservoir from the Bung Boraphet catchment, from the Chao Phraya River system in floods which exceeded $+24 \mathrm{~m}$ (MSL), or at other times if the lake level was less than the level of the Nan River and the control regulator was open (Figure 2).

Surface water flowed out from the reservoir in three ways. In the dry season there was a reverse flow from the reservoir into the catchment, as farmers collectively extracted water from the reservoir to irrigate their paddy rice, by pumping from locations in the stream network close to the reservoir. Secondly, the reservoir could spill when the stage height exceeded $+24 \mathrm{~m}$ (MSL) and it exceeded the level in the Chao Phraya River system. Thirdly, the reservoir manager (Thai Fisheries Department) could make controlled releases to the Nan or Chao Phraya Rivers, whenever the reservoir level exceeded the river levels.

We categorised outflows (upstream) into the reservoir catchment as regulated Outflow Type 1, which could be gauged, and Outflow Type 2, which could not be gauged. Type 1 outflows represented the net cumulative extraction by individual farmers pumping from the two streams and the irrigation canals upstream of the reservoir. This outflow occurred in the first part of the drawdown period, whilst the pump sites in the catchment were hydraulically connected to the reservoir. This outflow rate was controlled by the rate of pumping and the channel cross-section.

As the reservoir level fell, more and more farmland lost hydraulic connectivity until at a critical stage height, farmers constructed temporary check dams at a series of locations in the stream network, which completely severed the hydraulic connectivity between reservoir and catchment. The type 2 outflow periods were identifiable by catchment gauge levels exceeding the reservoir level during the drawdown part of the cycle (Figure 4).

Rating curves and flow rules

Staff gauges (precision $\pm 5 \mathrm{~mm}$ ) were installed near the mouths of the two main natural streams and two irrigation canals constructed to irrigate areas that cannot access natural streams. These sites represented more than $96 \%$ of the catchment drainage. The remaining direct runoff into the reservoir was included in the residual term. Manual observations were made of stream level (three times a day and averaged) and reservoir level once each day (Figure 1). 
Separate inflow and outflow rating curves were prepared for each stream from measurements of flow rate and channel cross section at the staff gauge locations. The volume of surface water that flowed into or out of the reservoir each day was calculated using the appropriate rating curves and level observations. The flows in K. Bon and the Irrigation Canals were always confined within the channel and so were described by single rating curves. However, when the reservoir water level exceeded $+24.30 \mathrm{~m}$ (MSL), the outlet of $\mathrm{K}$. Tatako was submerged, so a second rating curve was prepared for this location to estimate the volume of overbank flow. A set of flow rules were developed to determine when each rating curve should be used (Table 1).

Figure 4. Reservoir and streams level relationships used to define flow periods in each hydrological cycle used in this study. (Note: Stream level observations were not used to calculate Outflow Type 2 volumes).

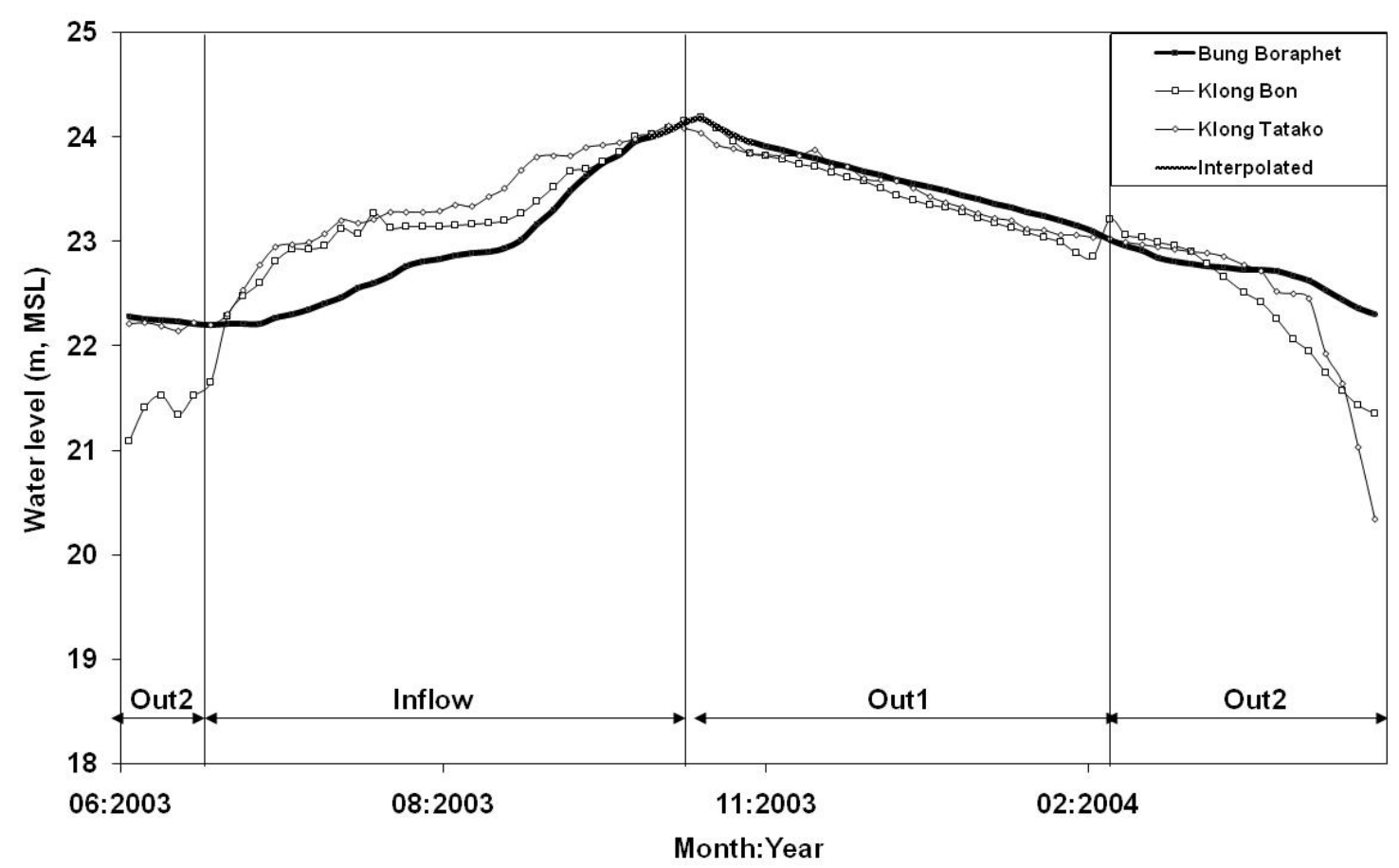

Table 1. Description of the surface flow rating curves.

\begin{tabular}{|c|c|c|c|}
\hline Flow direction & Flow Type & Description & Curve Rule $\dagger$ \\
\hline $\begin{array}{l}\text { Into the } \\
\text { reservoir }\end{array}$ & $\begin{array}{l}\text { Regulated } \\
\text { inflow }\end{array}$ & Inflows from the catchment under gravity & $\begin{array}{l}\text { Stream stage }> \\
\text { Reservoir stage }\end{array}$ \\
\hline $\begin{array}{l}\text { Out of the } \\
\text { reservoir }\end{array}$ & $\begin{array}{l}\text { Regulated } \\
\text { Outflow Type } 1\end{array}$ & $\begin{array}{l}\text { Outflow from the reservoir to the catchment } \\
\text { by pumped extraction from streams } \\
\text { hydraulically connected to the reservoir }\end{array}$ & $\begin{array}{l}\text { Stream stage }< \\
\text { Reservoir stage }\end{array}$ \\
\hline $\begin{array}{l}\text { Out of the } \\
\text { reservoir }\end{array}$ & $\begin{array}{l}\text { Regulated } \\
\text { Outflow Type } 2\end{array}$ & $\begin{array}{l}\text { Outflow from the reservoir to the catchment } \\
\text { by pumped extraction when check dams are } \\
\text { constructed in the stream network. Rating } \\
\text { curves were not applicable during this period. }\end{array}$ & $\begin{array}{l}\text { Stream stage }> \\
\text { Reservoir stage } \\
\text { in the dry season }\end{array}$ \\
\hline
\end{tabular}

$\uparrow$ Curve Rule to determine when to change the rating curves or when rating curves do not apply. 


\subsubsection{Direct rainfall $\left(I_{r}\right)$}

The rainfall onto the reservoir surface from 2002 to April 2005 was estimated from rainfall measured $10 \mathrm{~km}$ west of Bung Boraphet, at Muang Nakhon Sawan Meteorological Station. After 1 May 2005, Standard 8 inch Rain Gauges (precision of measurement of $\pm 0.05 \mathrm{~mm}$ ), were installed at four new stations around the reservoir shore. The daily rainfall onto the reservoir from May 2005 until May 2006 was calculated using the data from Nakhon Sawan plus the four reservoir side stations using the Thiessen Polygon areal weighting method [16]. The daily increase in water volume in the reservoir attributed to rain fall was calculated as rainfall depth multiplied by reservoir surface area on that day (Figure 3).

\subsubsection{Evaporation $(E T)$}

The daily evaporation from Bung Boraphet was calculated using the modified Penman equation [17] with data collected at the Meteorological Station at Nakhon Sawan, $10 \mathrm{~km}$ from the reservoir.

\subsubsection{Stored water volume (S)}

The water level in Bung Boraphet has been measured daily since April 1993, by the Thai Fisheries Department from a staff gauge near the regulator to the Nan River (precision of $\pm 5 \mathrm{~mm}$ ). The daily change in the stored water volume of Bung Boraphet ( $\Delta \mathrm{S} / \Delta \mathrm{t}$ from eq. 1) was calculated from the volume-elevation curve and the observed water levels.

The bathymetry of the reservoir has been mapped at 0.5 meter intervals, from a depth survey on a $150 \times 200 \mathrm{~m}$ grid conducted in 2003 [9]. The volume and area - elevation curves were interpolated from the $0.5 \mathrm{~m}$ contour chart. Thus the linear interpolated value for reservoir volume at FSL was $177.5 \times 10^{6} \mathrm{~m}^{3}$ and the uncertainty (observation error) at FSL was $\pm 2.82 \times 10^{6} \mathrm{~m}^{3}$.

\subsubsection{Error terms}

The volume of each measured component in the annual inflow-outflow cycle was multiplied by the percent error associated with the respective measurement method to estimate the error in the volume of that component (Table 2), which represented 1 SD for that component [18]. The uncertainty in the seepage estimate was not estimated as it was calculated from the residual.

The residual term $(e)$ in the water balance equation, comprised measurement uncertainty associated with the estimates of the major components of the budget listed in Table 2. In order of decreasing methodological uncertainty these were: 1) uncertainty associated with applying rainfall and meteorological data from distant locations to the reservoir; 2) systematic errors associated with rating curves and volume and area elevation curves; 3 ) random type error due to measurement precision; and 4) systematic underestimate of inflow from the small fraction $(<1 \%)$ of ungauged catchment.

The systematic extraction of water from the reservoir for aquaculture and potable supply were not modeled independently but included in the residual term as they were small relative to the main water balance components. Approximately $10^{4} \mathrm{~m}^{3} \mathrm{~d}^{-1}$ was extracted to maintain aquaculture [3] and the Tatako District Waterworks Authority extracted a similar volume in the dry season, between December and February each year to supply domestic users [3]. 
In addition to the measurement uncertainty, the residual error also included two important unmeasured terms. The inflow and outflow of groundwater and the ungauged extraction during the outflow type 2 period.

Table 2. Methods of estimation of model variables and uncertainty in each.

\begin{tabular}{lllll}
\hline Variable & Description & $\begin{array}{l}\text { Obs. } \\
\text { Error } \dagger\end{array}$ & Method & Method Error $\neq$ \\
\hline $\mathrm{I}_{\mathrm{P}}$ & Precipitation & 0.05 & Rain gauge & $20 \%$ \\
$\mathrm{I}_{\mathrm{s}}$ & Surface inflow & 5 & Staff gauge and rating curve & $15 \%$ \\
$\mathrm{O}_{\mathrm{ET}}$ & Evaporation & $\mathrm{nd}$ & Climatic model (Penman) & $20 \%$ \\
$\mathrm{O}_{\mathrm{s} 1}$ & Outflow Type 1 & 5 & Staff gauge and rating curve & $15 \%$ \\
$\Delta \mathrm{S}$ & change in volume & $5 \mathrm{~mm}$ & staff gauge error and hypsograph & $10 \%$ \\
$\mathrm{~S}_{\mathrm{T}}$ & Total Error (1 SD) & & $\sqrt{(\text { sum of squares of obs. components) }}$ & \\
$\mathrm{O}_{\mathrm{s} 2}$ & Outflow Type 2 & $5 \mathrm{~mm}$ & residual error & \\
$\mathrm{I}_{\mathrm{g}} / \mathrm{O}_{\mathrm{g}}$ & Seepage in/out & $5 \mathrm{~mm}$ & residual error & \\
\hline
\end{tabular}

†Error in measurement method (after LaBaugh and Winter, 1984); nd - not determined.

$\dagger$ Uncertainty in making an observation.

\subsubsection{Groundwater exchange $(G w)$}

Ground-water exchange is a complex hydrologic property, and accurate measurement of daily ground-water exchange in floodplain wetland systems is time-consuming, difficult, and expensive [12,19].

Groundwater loss is often considered a minor component of the annual water budget in floodplain lakes, which occur in sedimentary environments with low hydraulic conductivities, e.g., [13]. For these reasons, we did not directly measure the groundwater contribution to the reservoir water budget and it was initially assigned to the residuals term of the water balance (eq. 1).

However, the regular cycle of flood plain inundation means that groundwater inflow may be an important seasonal component of flood plain lake hydrology and ecology [19]. Therefore we analysed the residual term of the water balance model to derive a seasonal estimate of the seepage flux between the reservoir and the groundwater.

During the Type 1 Outflow periods there were no inflows so equation 1 simplified to:

$$
\mathrm{Gw}=\Delta \mathrm{H}-\mathrm{ET}-\Sigma \mathrm{O}_{\mathrm{T} 1}-A_{w} \quad\left(\text { as } \Sigma \mathrm{I}_{\mathrm{s}}=\mathrm{I}_{\mathrm{r}}=0\right)
$$

where $\mathrm{Gw}$ was the net inflow or outflow attributed to seepage, in $\mathrm{mm} \mathrm{d}^{-1}$;

$\Delta \mathrm{H}$ was the change in reservoir level in $\mathrm{mm} \mathrm{d}^{-1}$;

$\Sigma \mathrm{O}_{\mathrm{T} 1}$ was the total Type 1 Outflow in $\mathrm{mm} \mathrm{d}^{-1}$; and

$A_{w}$ was the average daily extraction for aquaculture and potable use (in $\mathrm{mm} \mathrm{d}^{-1}$ ). 
At these times the residual error term simplified to 1) random type error due to measurement precision; 2) systematic errors associated with volume and area elevation curves; 5) variable unmeasured seepage inflow or outflow; and 6) a systematic loss to aquaculture and potable supply.

Measurement errors were random (either positive or negative), whilst the seepage component was assumed to be constant (either positive or negative) over the course of a flow season, whilst the daily loss to 'other use' (aquaculture and domestic potable use) was assumed as a constant throughout the outflow periods.

The mean seepage for each inflow and Outflow type 1 period was estimated from the slope of the line of best fit through the daily residuals, corrected for a systematic loss to 'other use' in the dry season which was $2 \times 10^{4} \mathrm{~m}^{3} / \mathrm{d}$ during Outflow type 1 and $1 \times 10^{4} \mathrm{~m}^{3} / \mathrm{d}$ in Outflow type 2 (= an average change in level of $0.45 \mathrm{~mm} / \mathrm{d}$ ).

Seepage could not be estimated in this way during the Outflow type 2 periods as the stream outflow volumes were ungauged. However, as the hydraulic conditions were assumed to remain relatively constant throughout the Outflow period, the seepage co-efficient from Outflow type 1 was extrapolated to the Outflow type 2 period of each drawdown cycle.

The losses to aquaculture and potable use of $2 \times 10^{4} \mathrm{~m}^{3} \mathrm{~d}^{-1}$ in the dry season were also included in the residual term. These extractions corresponded to a fall in reservoir level of between 0.3 and $0.6 \mathrm{~mm}$ per day, which was significant when compared to the groundwater seepage rates estimated from the residual term. Therefore seepage estimates during the dry season (Outflow periods) were corrected for the aquaculture and potable supply components by subtracting $0.45 \mathrm{~mm} / \mathrm{d}$.

\subsubsection{Outflow type 2}

As the daily volume of Type 2 outflows could not be determined by the rating curve method, these were estimated from the difference between the change in the observed reservoir volume and the sum of the other model parameter components (eq. 3).

$$
\mathrm{O}_{\mathrm{T} 2}=\mathrm{I}_{\mathrm{r}}-\Delta \mathrm{S}-\mathrm{Gw}-\mathrm{ET}-A_{w+} e
$$

where $O_{T 2}$ was the total Type 2 Outflow;

$\Delta \mathrm{S}$ was the daily reservoir volume change;

Gw was the net seepage flow estimated in the preceding Outflow type 1;

ET was the evaporation;

$I_{r}$ was the volume of rainfall on the reservoir;

$A_{w}$ was the average daily extraction for aquaculture and potable use; and

$e$ is a residual error term representing method and measurement errors.

\subsection{Demand modeling}

The outflows from Bung Boraphet upstream to the catchment were almost exclusively for irrigation of paddy rice. Therefore as a validation of the water balance model and as an estimate of the effectiveness of resource usage, we determined the area of rice which could be optimally irrigated in the dry season, using water volumes derived from the water balance and an irrigation demand model [20]. 
The irrigation efficiency $\left(\mathrm{E}_{i}\right)$ was established for an irrigated area of $76 \mathrm{~km}^{2}$ reported by [4] for the Outflow 1 period of November 2003 to February 2004 and this Ei was assumed in the subsequent years.

\section{Results}

The hydrodynamic behaviour of Bung Boraphet was highly cyclic. A uni-modal filling phase commenced in mid-year and a prolonged drawdown followed from October-November. This annual cycle is evident in daily records of reservoir level since the weir was raised to +24 MSL in 1993 (Figure 5). Over that period the annual maximum level exceeded the weir height in 11 of 14 years. More significantly, there have been 3 major floods in the Chao Phraya River system, identified by maximum water levels more than $2 \mathrm{~m}$ above the weir, which inundated large areas of the Chao Phraya flood plain including the Bung Boraphet wetland. The inflow-outflow cycle in Bung Boraphet that we used in this analysis always lagged the start of the official Thai water year (1 April and 31 March). The first inflow to Bung Boraphet followed the onset of the monsoon and was usually 6-8 weeks after the start of the water year. This variability in the start of the cycle, plus interannual differences in the magnitude of the flood, meant the duration of the natural cycle varied between 261 and 431 days during this study (Table 3).

Figure 5. Daily observations of water level of Bung Boraphet (1993-2006).

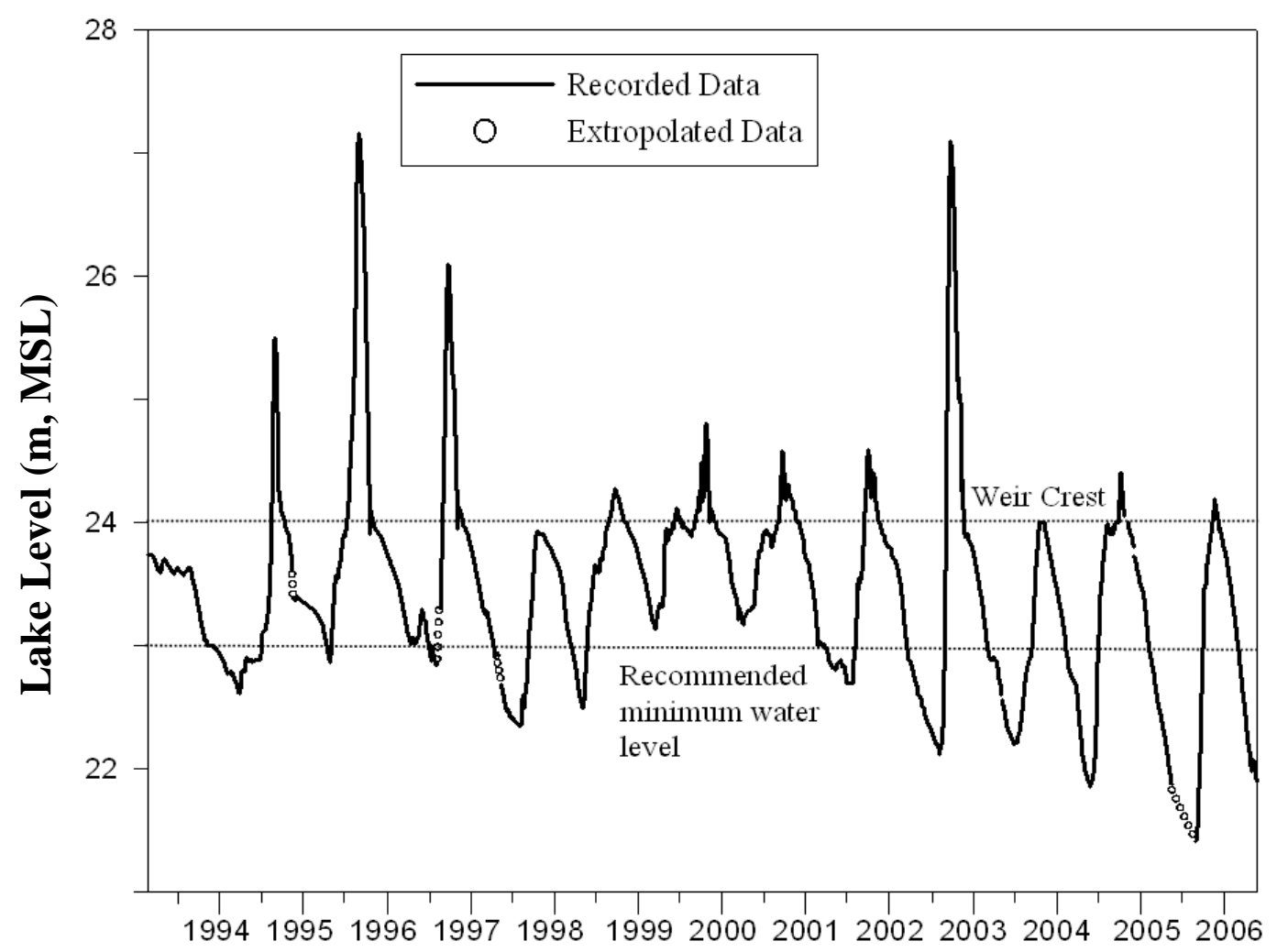

The volume of each component of the water budget was calculated for each season in three complete inflow/outflow cycles from 2003 to 2006 (Table 3 and Figure 6). A very large surface water inflow from the Chao Phraya River preceded the commencement of this study in 2002, but during the 
study period there was only a single minor inflow from Nan River in 2003. Thus this study was an opportunity to accurately assess the contribution of the local catchment to the water budget of the reservoir, in the absence of ungauged input from the Chao Phraya River.

Table 3. Summary of water balance components for three inflow/outflow cycles.

\begin{tabular}{|c|c|c|c|c|}
\hline & & 2003-04 & 2004-05 & 2005-06 \\
\hline \multirow[t]{9}{*}{ Losses } & $\left(10^{6} \mathrm{~m}^{3}\right)$ & & & \\
\hline & Evaporation & 83 & 137 & 89 \\
\hline & Net Seepage outflow & 4 & 48 & 12 \\
\hline & Outflow Type1 & 78 & 64 & 44 \\
\hline & Outflow Type2 & 13 & 20 & 8 \\
\hline & Total Irrigation outflows & 91 & 84 & 52 \\
\hline & Outflow to CP $\ddagger$ & 4 & 22 & 6 \\
\hline & Outflow to Others§ & 3 & 5 & 3 \\
\hline & Total of loss terms & 186 & 295 & 162 \\
\hline \multirow[t]{9}{*}{ Gains } & $\left(10^{6} \mathrm{~m}^{3}\right)$ & & & \\
\hline & K. Bon & 19 & 20 & 25 \\
\hline & K. Tatako & 151 & 118 & 147 \\
\hline & Irrigation Canals & 4 & 6 & 4 \\
\hline & Stream inflows & 174 & 145 & 176 \\
\hline & Direct rainfall & 33 & 100 & 73 \\
\hline & Inflow from $\mathrm{CP} \ddagger$ & 0 & 6 & 2 \\
\hline & Net Seepage inflow & 2 & 4 & 0 \\
\hline & Total of gain terms & 210 & 255 & 251 \\
\hline \multicolumn{2}{|l|}{ Net Storage } & 28 & -36 & 92 \\
\hline \multicolumn{2}{|c|}{ Total error (1 SD) } & 41 & 42 & 41 \\
\hline Duration & of Outflow period (d) & 202 & 309 & 158 \\
\hline Duration $\uparrow$ & of annual cycle (d) & 311 & 431 & 261 \\
\hline
\end{tabular}

$\dagger$ The annual hydrological cycle for Bung Boraphet was determined from the beginning of rising reservoir level to end of falling level in the same cycle.

¥ Chao Phraya River system.

$\S$ Other quantified uses were for aquaculture (Outflow type 1 and 2) and potable supply (Outflow type 1).

\subsection{Surface water flows}

Stream gauges were installed on the four main streams for this project. Although there were no control structures at the gauge sites, rating curve data was gathered over the duration of the project, so the error in these curves was expected to be within the normal range for such curves. The rating curve coefficients are listed in the Appendices.

Surface runoff from the Bung Boraphet catchment was the most important gain term in the water budget. The main source of surface water was K. Tatako. The inflow from K. Bon was about 15\% of 
that from K. Tatako in each cycle and the contributions from two irrigation canals were minor (Table 3).

The specific yield of the Bung Boraphet catchment was $39,000 \mathrm{~m}^{3} \mathrm{~km}^{-2} \mathrm{y}^{-1}$ which was significantly lower than the yields from the two much larger tributaries of the Chao Phraya River, namely the Ping River $\left(150,000 \mathrm{~m}^{3} \mathrm{~km}^{-2} \mathrm{y}^{-1}\right)$ and Nan River $\left(339,000 \mathrm{~m}^{3} \mathrm{~km}^{-2} \mathrm{y}^{-1}\right)$.

Figure 6. Volume of water $\left(10^{6} \mathrm{~m}^{3}\right)$ for water balance components over three complete inflow outflow cycles between November 2003 and May 2006. One standard deviation (SD) of the total error in the volume is super-imposed on the outflow summary. It was $\sim 4010{ }^{6} \mathrm{~m}^{3}$ each year.

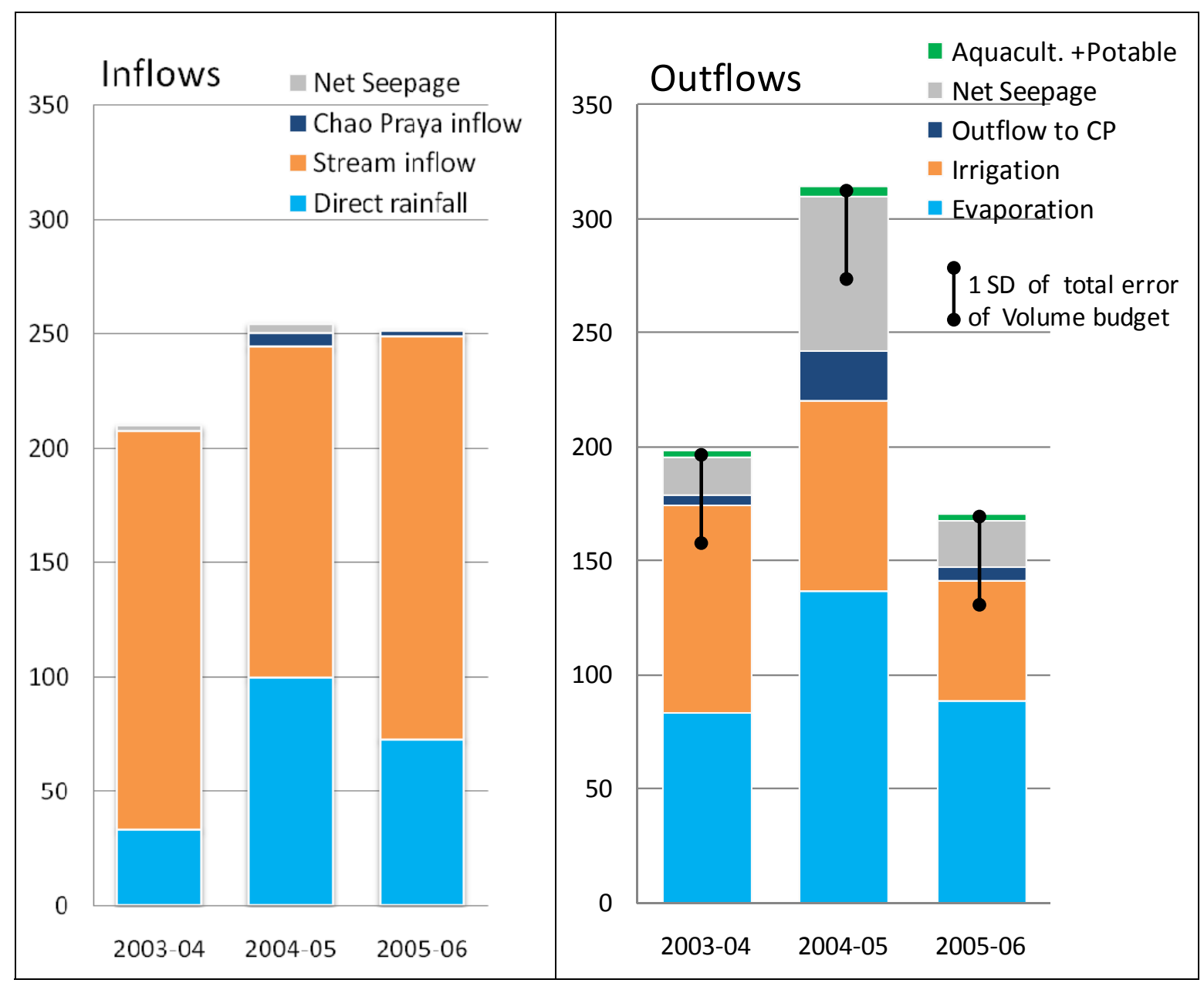

\subsection{Rainfall}

Rainfall in the Bung Boraphet catchment was highly seasonal. The majority of the precipitation occurring during the monsoon period (May to October) and in the wetter years more than $80 \%$ of the direct rainfall on the reservoir fell during this period.

Direct rainfall contributed $16-40 \%$ of the total input. The 2003 inflow season was comparatively dry and direct rainfall only contributed $16 \%$ of the total input of water to the reservoir whereas in 2004-5 and 2005-6 the direct rainfall onto the reservoir was 30 and 40\% respectively of the total gain. 


\subsection{Evaporation}

The average annual evaporation from Bung Boraphet was $1770 \mathrm{~mm} / \mathrm{y}$ and evaporation was the dominant loss term in the budget, contributing about $50 \%$ of the water loss in each cycle. The mean depth of the reservoir at FSL is 1.2 metres and does not vary much across the drawdown range. Therefore evaporation was always a significant loss factor at any storage level.

Over the duration of the study, the total volume of loss by evaporation was 1.5 times greater than the gain from direct rainfall onto the reservoir. However, the volume of water lost to evaporation varied between cycles principally because of differences in cycle duration.

\subsection{Surface water outflows}

The surface water outflow components of the budget were; 1) outflows via the catchment streams; 2) outflows for other uses (public water supply and aquaculture); and 3) discharges downstream via the weir or the Nan River regulator. Outflow to the catchment occurred during the dry season, when farmers extracted reservoir water via the streams, to irrigate paddy rice.

The outflow rating curves for each catchment stream had slightly poorer correlation coefficients than the inflow curves (see Appendices) because outflows were rated in conditions of variable pumping rates, whereas inflow (driven by gravity) was less variable. This was true for all streams except Irrigation Canal 1 - which had the least rating flow measurements.

Irrigation outflows were the second largest loss term in the water budget. The range, 92-58 $\times 10^{6} \mathrm{~m}^{3}$, represented $50 \%$ and $30 \%$ of the total losses for the respective years (Table 3 and Figure 6). The volume of the irrigation outflow varied more than evaporation between cycles as it depended not only on the volume of water in the reservoir available for extraction but also environmental factors like catchment runoff and farmers decisions on the profitability of a second or third rice crop.

Gauged outflows (type 1) occurred at the beginning of the drawdown cycle and were used to irrigate a second rice crop. These outflows comprised the greatest extraction volume each year. Ungauged outflows (type 2) occurred later in the drawdown period, when the reservoir level fell to about $+22.8 \mathrm{~m}$ and farmers constructed temporary check dams in the stream network to continue extracting reservoir water. The change from Outflow type 1 to type 2 was confirmed when levels at catchment gauge stations exceeded the reservoir level (Figure 4).

The volume of ungauged Outflow type 2 represented less than $10 \%$ of the total inflow in two years but in $2004-05$, it rose to $28 \%$ of the inflow, and comprised $20 \%$ of volume extracted for irrigation. These outflows were generally used to irrigate a third rice crop in the year. These outflows occurred late in the dry season when all other inputs were negligible, so reservoir drawdown was exaggerated by this use. In 2004-5, the largest type 2 Outflow of the three cycles studied coincided with the lowest reservoir level since the weir was raised in 1993.

The smallest loss term during the study was the volume discharged downstream. There were minor discharges over the control structures at maximum reservoir level in 2003-04 and 2004-05. Although a fishway is incorporated in the weir, there were no recorded releases when the reservoir was below Full Supply Level (FSL), so water exchange between Bung Boraphet and the Chao Phraya River system was very limited during the study period. 
Reservoir levels above FSL were not recorded in 2003 (Figure 7), due to operator error. However, the outflow volumes at those times were estimated by substituting levels from the catchment streams, which would slightly over-estimate the volume discharged.

Figure 7. Observations of the reservoir stage height over the study period vs. predicted values. (Note: observed $=$ observed level; predicted $=$ predicted level for inflow and Outflow 1periods; interpolated data for unrecorded reservoir levels).

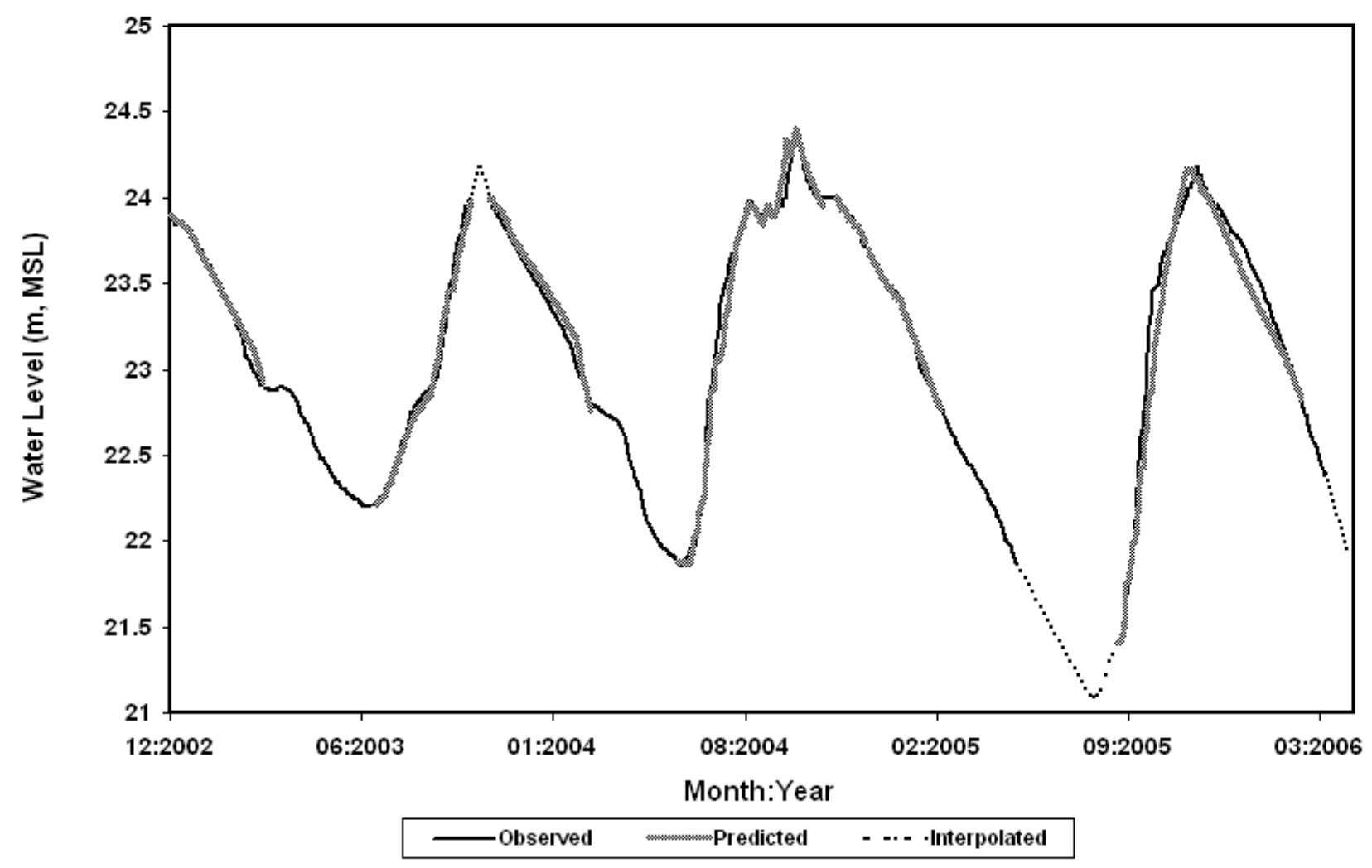

\subsection{Seepage}

A major flood in the Chao Phraya system in 2002 peaked at a height of $+27.2 \mathrm{~m}$ (MSL) in Bung Boraphet and temporarily inundated more than $880 \mathrm{~km}^{2}$ of the Bung Boraphet catchment (Table 4). After this inundation event, groundwater seeped into the reservoir from bank storage at a diminishing rate until 2004. Overlaid on this multiyear trend of a diminishing seepage into the reservoir was a seasonal cycle of seepage loss during the inflow season and seepage gains (or lesser loss) during the outflow season.

The mean daily seepage component of the budget for inflow periods varied between a gain of $0.8 \mathrm{~mm} / \mathrm{d}$ and a loss of $0.3 \mathrm{~mm} / \mathrm{d}$. During the outflows the maximum gain was $1.1 \mathrm{~mm} / \mathrm{d}$ in 2003 after the Chao Phraya River flood and the maximum loss was $2.2 \mathrm{~mm} / \mathrm{d}$ in 2005 (Table 4).

The gross seepage flux for each annual cycle (Table 3) was calculated from the sum of the seasonal seepage terms (see Table 4). Overall, there was a net seepage loss from the reservoir in every hydrological cycle. The magnitude of the loss ranged from 1\% of the total losses in 2003-04 (after the 2002 flood), to $15 \%$ in $2004-5$ when inflows were lowest and drawdown most prolonged. The greater 
seepage losses in 2004-2006 were presumably because the minor floods in those years did not recharge the bank storage in the same way as in 2002 (Table 4).

Table 4. Seasonal seepage co-efficients for each water cycle.

\begin{tabular}{lcccccc}
\hline Period & Start Date & $\begin{array}{c}\text { Duration } \\
(d)\end{array}$ & $\begin{array}{c}\text { Reservoir } \\
\text { starting level } \\
(\mathrm{m}, \mathrm{MSL})\end{array}$ & $\begin{array}{c}\text { max level } \\
(\mathrm{m}, \mathrm{MSL})\end{array}$ & $\begin{array}{c}\text { Temporary } \\
\text { inundated Area } \dagger \\
\left(\mathrm{km}^{2}\right)\end{array}$ & $\begin{array}{c}\text { Net Seepage } \\
(\mathrm{mm} / \mathrm{d}) \ddagger\end{array}$ \\
\hline Inflow & 1-Jul-02 & 123 & 22.2 & 27.20 & 882 & nd \\
Out type 1 & 11-Dec-02 & 89 & 27.2 & & & -1.23 \\
Inflow & 15-Jul-03 & 99 & 22.3 & 24.00 & 116 & -0.30 \\
Out type 1 & 10-Nov-03 & 105 & 24.0 & & & -0.02 \\
Inflow & 24-May-04 & 122 & 22.0 & 24.50 & 229 & -0.34 \\
Out type 1 & 24-Sep-04 & 151 & 24.5 & & & 2.02 \\
Inflow & 26-Aug-05 & 79 & 21.5 & 24.20 & 123 & 0.80 \\
Out type 1 & 14-Nov-05 & 112 & 24.2 & & & 0.20 \\
\hline
\end{tabular}

$\dagger$ Difference in inundated area from low water (permanent lake) to the following annual high water

$\ddagger$ Seepage calculated from residual error and then corrected for the daily loss to other minor uses. +ve seepage represents a flow out of the reservoir; nd - not determined

\subsection{Water budget model calibration and validation}

The water-budget model was developed using Excel software (Microsoft Excel 2003) with daily time steps. The model was validated for all inflow and Outflow type 1 periods, by comparing the predicted daily change in stored volume $(\Delta \mathrm{S} / \Delta \mathrm{t}$ in eq. 1$)$ to the observed change. There were several short periods when reservoir level was not recorded. The level change during those times was assumed to be linear (Figure 7).

The accuracy of the reservoir water budget model (eq. 1) was evaluated by comparing the daily reservoir water level observations with model predictions for inflow and Outflow type 1 periods between December 2002 and May 2006 (Figure 7). The flow characteristics for each flow period were different, so the appropriate co-efficients for flow prediction were set at the start of each flow period.

Statistical assessments of goodness of fit of model prediction of water level to the observations for inflow and Outflow period 1 were all satisfactory (Correlation coefficient [21] $r=0.98$ - best fit when $\mathrm{r}=1$; Root mean square error [22] $=0.09$ with best fit when $\mathrm{RMSE}=0$; Nash-Sutcliffe criterion [23] $=96.8 \%$ with best fit when EI $=100 \%$ ).

The results of the statistical analyses gives confidence that the water budget model can accurately estimate the contribution of different components of the water balance during periods in 2003 and 2005, when the reservoir level was not recorded.

\subsection{Demand model results}

The demand model derived irrigation efficiency $\left(E_{i}\right)$ for Outflow 1 flow in 2003-2004 was 42\%. This was very similar to the dry season $E_{i}$ (averaged over 4 years) of $43.4 \%$, reported by [24] for 
irrigated paddy rice areas in the Chao Phraya Basin adjacent to Bung Boraphet. We applied the same $E_{i}$ and used the irrigation demand model to estimate the optimum area for irrigation in the Outflow 1 and 2 periods of the following dry seasons (2004-2006) (Table 5).

Table 5. Mean water losses and estimated irrigated area during Outflows.

\begin{tabular}{|c|c|c|c|c|c|c|c|}
\hline \multicolumn{3}{|c|}{ Period } & \multicolumn{3}{|c|}{$\begin{array}{l}\text { Mean rate of Loss } \\
\qquad 10^{6} \mathrm{~m}^{3} \mathrm{~d}^{-1}\end{array}$} & \multirow{2}{*}{$\begin{array}{c}\text { Reservoir } \\
\text { Stage ht } \\
\text { to begin period } \\
\text { (m, MSL) }\end{array}$} & \multirow{2}{*}{$\begin{array}{c}\begin{array}{c}\text { Optimum } \\
\text { Irrigated Area* }\end{array} \\
\mathrm{km}^{2}\end{array}$} \\
\hline Type & Start date & $\begin{array}{l}\text { Duration } \\
\text { (days) }\end{array}$ & Net Evapn $\dagger$ & Irrigat. & Seepage & & \\
\hline Y2 Out 1 & 02-Nov-03 & 113 & -0.21 & -0.69 & -0.04 & +24.0 & 76 \\
\hline Y3 Out 1 & 24-Sep-04 & 151 & -0.28 & -0.42 & -0.26 & +24.5 & 54 \\
\hline Y4 Out 1 & 14-Nov-05 & 112 & -0.41 & -0.39 & -0.07 & +24.2 & 40 \\
\hline Y2 Out 2 & 24-Feb-04 & 89 & -0.25 & -0.15 & -0.02 & +22.6 & 22 \\
\hline Y3 Out 2 & 23-Feb-05 & 158 & -0.11 & -0.13 & -0.07 & +23.2 & 10 \\
\hline Y4 Out 2 & 07-Mar-06 & 46 & -0.31 & -0.19 & -0.03 & +23.0 & 9 \\
\hline
\end{tabular}

$\dagger$ Evaporation plus precipitation (precipitation was usually very low in these seasons)

I Ratio of Irrigation (I) to Evaporation (E)

$\S$ Ratio of rate of Outflow $2(\mathrm{O} 2)$ to rate of Outflow $1(\mathrm{O} 1)$

* Estimate of the optimum area for irrigation (from demand model with irrigation efficiency of $42 \%$ )

\subsection{Errors in measurement}

The total error in the measured components of the water balance cannot be calculated directly from the sum of the individual component error volumes, because the sign of the error for each component may be positive or negative with respect to the true value. We used the method of [18] to determine the standard deviation (SD) in the total error from the sum of the variance of all the measured components (eq. 4):

$$
\mathrm{S}_{\mathrm{T}}^{2}=\mathrm{S}_{\mathrm{Is}}^{2}+\mathrm{S}_{\mathrm{Ir}}^{2}+\mathrm{S}_{E T}^{2}+\mathrm{S}_{\mathrm{Os}}^{2}+\mathrm{S}_{\Delta \mathrm{S}}^{2}
$$

where $\mathrm{S}_{\mathrm{T}}{ }^{2}$ is variance of the total error in volume of the water budget;

$\mathrm{S}_{\mathrm{i}}{ }^{2}$ is variance of error in volume for measured component $\mathrm{I}$; and

$\mathrm{S}_{\mathrm{T}}$ is $1 \mathrm{SD}$ of the total error in volume of the water budget.

The total error is most sensitive to uncertainty in measurement of the largest terms (i.e. evaporation, inflow and outflow) and least sensitive to uncertainty in measurement of smaller terms like change in storage volume. The standard deviation (SD) of the total error was close to constant each year with 1 $\mathrm{SD} \sim 40 \times 10^{6} \mathrm{~m}^{3}$ (Figure 6). The measurement error for each component converted to volume is reported in the Appendices. The residual term was $<10 \%$ of the total water input to Bung Boraphet in the first and last annual cycle. However, in 2004-05 the residual term, which includes seepage and outflow type 2 , was $28 \%$ of the total outflow. More precise, automated records of reservoir level would improve the reliability of future water balances and the accuracy of the seepage estimate. 


\section{Discussion}

\subsection{Surface water inflows}

The hydrological characteristics of the Bung Boraphet catchment streams were similar to those of the much larger tributaries of the Chao Phraya River at Nakhon Sawan described by [15]. However, the specific yield of the Bung Boraphet catchment $\left(38,500 \mathrm{~m}^{3} \mathrm{~km}^{-2} \mathrm{y}^{-1}\right)$ was significantly less than for the larger rivers (e.g., 26\% and 11\% respectively of the Ping and Nan catchment yields). This may be due to the larger proportion of agricultural landuse - especially intensive rice cultivation - in the Bung Boraphet catchment, which would intercept and detain surface water inflows.

All surface flow monitoring sites in the stream network were close to the reservoir. Thus the water budget model only calculated water withdrawals from the reservoir. It did not include the volume extracted from streams during inflow periods.

\subsection{Rainfall}

Direct rainfall was a significant component of the budget as the reservoir has such a large surface area. The very low volume of direct rainfall in 2003-4 was anomalous, considering the total stream discharge in that cycle was equal highest. The difference in rainfall between cycles was unlikely to be solely due to the increased gauge coverage that occurred in April 2005 and improved the accuracy of rainfall estimates in the final inflow period. It may be another indicator of the contribution of intensive farming to the low specific yield from this catchment.

\subsection{Surface water outflows}

This assessment of the water budget was based on the rise and fall of the reservoir water level in inflow outflow cycles. The cycles were not uniform in duration, and this variability had greatest effect on the size of the evaporation term. Thus, when reservoir water levels fell to a record low in 2005, it was mainly because the 2004 wet season finished early and the 2005 wet season was late. It was 309 days from the start of outflow in September 2004 until the reservoir level rose again in August 2005. The net evaporation over this extended outflow was $50 \%$ more than for the shorter cycles. Seepage was also significantly higher than in other years, whereas extraction for irrigation was relatively constant.

The outflows to irrigate rice in the catchment were the second largest loss term in the water budget. Demand for water for irrigation has increased throughout the Chao Phraya River floodplain over the past two decades, as technological advances permitted cultivation of two or even three rice crops per year [5]. In the Bung Boraphet catchment, the increase in demand due to multiple crops per year has been further exacerbated by a doubling in the area of rice paddy [4] and the dry season drawdown observed in each hydrological cycle of this study suggest that the area of dry season irrigation in the catchment is already periodically exceeding the storage capacity of the Bung Boraphet reservoir. 


\section{Irrigation demand}

A survey of Bung Boraphet farmers in 2002 reported that farmers would plant a second (dry season) rice crop on all irrigated paddy in the Bung Boraphet catchment, if the reservoir was full at the beginning of the dry season.

The farmers also reported that dry season rice yield varied from year to year depending on water availability. But since a new weir was constructed in 1993, the reservoir has always been full ( $\geq 24 \mathrm{~m})$ at the beginning of the dry season (Figure 5). Therefore reservoir level at the start of drawdown seemed to be a poor indicator of water availability.

Our study seemed to confirm this, because although the reservoir was $\geq 24 \mathrm{~m}$ at the beginning of drawdown in each year of this study, the volume extracted for irrigation progressively declined from $91 \times 10^{6} \mathrm{~m}^{3}(2003-04)$ to $53 \times 10^{6} \mathrm{~m}^{3}(2005-06)$ (Table 3 and Figure 6).

If we assume the entire irrigable area was planted to rice each dry season, the diminished irrigation supply after 2003 was either supplemented from other sources, or the crops received inadequate water and the yield suffered.

To answer this question, we compared the irrigation consumption with the net evaporation (evaporation less direct rainfall) and seepage terms during each Outflow season. The seasonal volumes were converted to daily rates to normalise for different seasonal durations to aid the comparison (Table 5).

The extraction rate in Outflow 1 periods was negatively correlated with the net evaporation rate. This is a clear indicator that the stored supply was insufficient because if the stored supply was in excess we would expect irrigation consumption to rise in drier years to match the loss from higher net evaporation. Conversely if the irrigated area is in excessive of the supply capacity of the storage, an increase in the seasonal net evaporation would further reduce the water available for irrigation use.

In summary, the evidence from water balance and the demand modeling indicated that if farmers cultivated $76 \mathrm{~km}^{2}$ of irrigated land for a second rice crop every dry season (as reported by survey), then the yields from the second (and third) crops in 2004-5 and 2005-6 would have been reduced by water resource limitation, despite full reservoir storage at the beginning of the dry season.

In the lower Chao Phraya basin, the anticipated price at harvest is the most important driver for dry season rice planting, even where the availability of irrigation water is controlled by a government agency [5]. In the Bung Boraphet catchment, where extraction is uncontrolled, crop price is also likely to be the dominant influence on farmer's planting decisions, perhaps aided by the farmer misconception that a full reservoir at the end of the wet season will provide sufficient water for the dry season crop.

\subsection{Evaporation}

Evaporation is a very important feature of the Bung Boraphet water balance as it was the largest loss term in 2 of the 3 years. The Bowen-ratio energy-budget (BREB) method is generally considered as a benchmark standard for measurement of evaporation and it is assumed to be within $10 \%$ of true values when averaged over a season and within $15 \%$ when averaged over a month [25]. The Penman method used in this study has also been widely applied in hydrological studies of reservoir water balance. The average annual evaporation rate of Bung Boraphet of $1,700 \mathrm{~mm} / \mathrm{y}$ was comparable to 
Penman evaporation estimates from other large shallow tropical lakes with a monsoonal climate (e.g. Lake Manton, Northern Territory Australia 1,971 mm/y [26] and Lake Ziway, Ethiopia $1,870 \mathrm{~mm} / \mathrm{y}$ [27].

We estimated the uncertainty in the Penman evaporation estimate used here was $20 \%$, based on the findings of [28] that $85 \%$ of the Penman estimates were within $20 \%$ of the BREB measure. The uncertainty in the evaporation estimate could be reduced by installing measurement instrumentation closer to the reservoir than in this study.

\subsection{Groundwater}

The residual term of reservoir water budgets includes all ungauged inputs and outputs. Although the net ungauged contribution to the Bung Boraphet water budget in this study were generally small ( $<10 \%$ of the total inflow in 2 of 3 hydrological cycles), evidence from other floodplain lakes has shown seepage into and out of the reservoir during the course of the annual inundation and drawdown cycle, can be significant [14,29].

The seepage behaviour of the Bung Boraphet reservoir was relatively complex. A regional flood event in 2002 provided bank storage sufficient to provide unidirectional seepage into the reservoir throughout the following muted hydrological cycle. The annual floods during this study period were much smaller than 2002 and by the 2004-5 cycle the seepage flux had reversed to become a net loss. Towards the end of the study, seasonal reversals in the direction of seepage which are typically associated with flood plain lakes became evident.

These results indicate that the magnitude and the duration of the annual flood have a dominant effect on the direction of subsequent seepage flows. Although seepage was the least significant net loss term in the budget, long term average seasonal seepage terms should only be applied with caution and a consideration of the magnitude of the annual flood in modeling different management options.

\subsection{Eco-hydrological implications of the changes in water balance}

The original Bung Boraphet weir was constructed to create a permanent reservoir fishery and this use is still an important use today. However, some of the hydrological management strategies advocated by Thailand's Department of Fisheries for the Bung Boraphet reservoir fishery conflict with the eco-hydrological principles for sustaining other wetland uses.

For example, floodplain wetland ecosystems are very sensitive to variability in the hydrological cycle, so that wide annual or interannual fluctuations in water level are normal and indeed beneficial to wetland productivity and functionality. A survey of the birdlife of Australian lakes and reservoirs showed water bird diversity was correlated with hydrological variability; natural wetlands had greatest diversity and reservoirs with tightly regulated levels had least [30].

The inundation ratio (seasonal: permanent flooded area) is an eco-hydrological indicator of potential wetland productivity. A local example of its use is as a predictor of the annual productivity of the Tonle Sap fishery (on the Mekong River flood plain) [31].

The inundation ratio of the Bung Boraphet reservoir- wetland during this study ranged from 3:1 to $12: 1$, which is comparable to the mean inundation ratio of $6: 1$ reported for wetlands on the Niger and the Senegal Rivers in Africa [32]. This suggests the recent trend towards an increasing inundation ratio 
in the Bung Boraphet wetland (as observed in this study) may be more beneficial to wetland health (diversity) and function (productivity), than maintenance of a regulated storage with minimum drawdown of $+23 \mathrm{~m}$ (MSL). It is noteworthy that fish diversity in Bung Boraphet is reported to have diminished significantly since it has been managed as a regulated reservoir.

There are benefits in maintaining the reservoir fishery as a closed system in the dry season. Flood plain lakes are recognized as the nurseries and recruitment areas for highly productive tropical river fisheries. Nutrients and silt that are transported on the floodplain by floodwaters are trapped and become available for use in subsequent aquatic and terrestrial phases of the inundations cycle. This process makes wetlands highly productive ecosystems. The wetland productivity is usually exported to the river system during the flood recession phase, but the discharge to the Chao Phraya River system was only $4.5 \%$ of the total input during this study. Thus wetland production is retained in the reservoir and the local fishery benefits at the expense of fish production throughout the Chao Phraya system.

However, this local benefit may be compromised if the minimum storage volume is not maintained (as occurred in each year of this study). During the prolonged dry season of 2005 the volume fell to $9 \%$ of the storage $(+21.4 \mathrm{~m}(\mathrm{MSL}))$. If fish cannot escape downstream from such extreme drawdown events, they will be concentrated in a diminishing area of open water, where growth is reduced by increased competition for food and predation is increased by water birds and illegal fishermen. The Bung Boraphet region recorded the highest level of convictions for illegal fishing in the 23 Thai fishing regions in $2004-5$ represent $14 \%$ of the national total [33].

Other fisheries management practices in Bung Boraphet seem to contradict best management practices used elsewhere. For example the Fishery Department has an operational target to dredge one million cubic metres of silt from Bung Boraphet reservoir every year, to maintain the reservoir volume and keep deeper water channels available for boat access and fish refuge [34]. This is a planned response to an estimated average annual deposition of 2.2 million cubic metres of sediment from the Chao Phraya system.

One could question whether ongoing dredging is an appropriate response to address a silt loading delivered by floods with a recurrence interval of 3-5 years. More important is the practical impact of the dredging activity in raising turbidity levels and reducing the submerged aquatic plant cover in the lower half of the reservoir [4].

Aquatic macrophyte beds provide nursery habitats for many fish species. Activities that increase the turbidity of macrophyte dominated shallow lakes risk switching the main primary production of these systems from macrophytes to phytoplankton with blooms of toxic cyanobacteria (blue green algae).

\subsection{Management}

Balancing consumptive water use with the eco-hydrological requirements of environmental resources is an important element of integrated water basin management for sustainable development [35]. The demand for water from the Bung Boraphet reservoir for dry season irrigation is now in excess of the storage volume and management of the irrigation demand will be imperative in the future. Understanding and careful accounting of the components of the reservoir water budget will be important in achieving a balance between the competing uses. Areas of uncertainty in components of the water budget identified in this study could be reduced by simple improvements in instrumentation 
(e.g., automated recording of reservoir level and measuring climatic factors at sites closer to the reservoir).

The current proposal for dry season diversions from the Nan River into the Bung Boraphet reservoir [10] to maintain the reservoir volume at $+23 \mathrm{~m}$ (MSL), seems ill conceived for several reasons. Firstly, dry season diversions from the Nan River would decrease the water flowing to the Chao Phraya delta, where farmers are also requesting a bigger dry season allocation [24]. Therefore, rice production would really be re-allocated not increased. Secondly, even temporary storage in the Bung Boraphet reservoir would result in a significant volume of diverted water being lost by evaporation. Thirdly, natural resource managers, farmers and even the public are likely to question the allocation of valuable dry season water for cultivation of rice in a designated conservation zone. Finally, the maintenance of a minimum reservoir level at $40 \%$ of the stored volume may be beneficial for the reservoir fishery, but detrimental to other properties of the system such as wetland bio-diversity and the productivity of the greater Chao Phraya river system.

\section{Conclusions}

A water balance model for the Bung Boraphet reservoir was developed from daily measurements over three annual inflow outflow cycles and used to prepare a reservoir water budget. There were no system wide floods during this study and monsoon derived surface water inflow from the local catchment was the dominant inflow term. A basin wide flood inundated the floodplain in the wet season of 2002, immediately before this study commenced, and that flood contributed to groundwater flows into the reservoir in 2003.

Evaporation was the biggest overall loss term. In two of the flow cycles evaporative loss was $\sim 86 \times 10^{6} \mathrm{~m}^{3}$. The outflow period of the 2004-2005 cycle was very long and evaporation reached $137 \times 10^{6} \mathrm{~m}^{3}$, which contributed to the extreme drawdown of the reservoir. Most of the irrigation extraction was gauged in each drawdown cycle (Outflow type 1) but in late drawdown the extraction had to be estimated by statistical analysis of the daily residual (Outflow type 2). The outflow for irrigation was the second largest loss term in the budget and averaged $76 \times 10^{6} \mathrm{~m}^{3} /$ cycle. Seepage was the smallest loss term. The direction and the magnitude of seepage flow were influenced by the extent and duration of the flood and there were net gains from seepage into the reservoir in some flow periods.

The uncertainty in total volume due to measurement was $\pm 40 \times 10^{6} \mathrm{~m}^{3}$ ( 1 standard deviation). This uncertainty would be reduced by improving the precision of the water level measurement and by establishing a new evaporation measurement station to closer to the reservoir.

Demand modeling showed that irrigation demand in the Bung Boraphet catchment exceeded the reservoir storage capacity and the catchment water yield in the dry season. Future management plans should focus on balancing the consumptive water needs with the hydrological requirements of the reservoir fishery and the requirement to sustain a diverse and productive wetland. The differing ecohydrological requirements of the fishery and the wetland need to be better understood to reconcile existing management practices with sustainable use in future.

Water balance models are a scientific way of identifying the relative contribution of different components of the water budget. Water budgets are an important step in matching the available 
resource with the hydrological requirements of different uses. This study has highlighted evaporation as the biggest contributor to water loss from the Bung Boraphet reservoir. The significance of evaporative loss should not be overlooked, when allocating Nan River water for dry season irrigation use within the Chao Phraya basin.

\section{Acknowledgements}

The authors gratefully acknowledge the Kasetsart University Research and Development Institute and Ramsar Small Grants Fund for financially supporting this research. We also would like to thank Mahidol University for financial support for the second author to carry out his $\mathrm{PhD}$ study. We wish to thank the Department of Fisheries and Thai Meteorological Department (TMD) for providing useful information for the water balance calculations. We are grateful to the many national and local government officers and people of Nakhon Sawan Province for their past support and their continuing interest and help. We also thank Nimal Chandrasena for his support and advice and last but by no means least, we are grateful to three anonymous reviewers whose critique helped us to improve the style and the content of the paper.

\section{References}

1. Talling, J.F. Environmental controls on the functioning of shallow tropical lakes. Hydrobiologia 2001, 458, 1-8.

2. ONREPP The Biodiversity in Bung Boraphet Wetland; Office of Natural Resources and Environmental Policy and Planning: Bangkok, Thailand, 2002.

3. Surakit, K. Integrated Water Resource Management For Bung Boraphet. Kasetsart University, Bangkok, 2007.

4. Sriwongsitanon, N.; Surakit, K.; Hawkins, P.; Chandrasena, N. Decision Support Tools for Water Resource Management: A Case Study of Bung Boraphet Wetland, Thailand. J. Develop. Sustain. Agric. 2007, 2, 17-26.

5. Molle, F. Technical and institutional responses to basin closure in the Chao Phraya river basin, Thailand. Wat. Int. 2004, 29, 70-80.

6. Pattanee, S. Challenges in Managing the Chao Phraya's Water. In Ninth International Riversymposium, Brisbane City Council, Brisbane, Australia, 4-7 September 2006.

7. Phongpaichit, P., Why the decision-making process on big projects has to change. In Seminar on Good Governance, Public Participation and Decision-making Process for Environmental Protection, Institute of Social and Economic Policy, Bangkok, Thailand, 18-19 March 2000.

8. Molle, F.; Floch, P. Megaprojects and Social and Environmental Changes: The Case of the Thai "Water Grid". Ambio 2008, 37, 199.

9. RID Final Report; Royal Irrigation Department: Bangkok, Thailand, 2003.

10. DWR The Feasibility Study, Survey and Detailed Design for Water Network System for Bung Boraphet, Nakhon Sawan; Department of Water Resources: Bangkok, Thailand, 2007.

11. Mansell, R.S.; Bloom, S.A.; Sun, G. A model for wetland hydrology: description and validation. Soil Sci. 2000, 384-397. 
12. Boone, R.; Johnson, C.; Johnson, L. Simulating Vernal Pool Hydrology In Central Minnesota, USA. Wetlands 2006, 26, 581-592.

13. Hamilton, S.K.; Lewis, W.M., Jr. Causes of seasonality in the chemistry of a lake on the Orinoco River floodplain, Venezuela. Limnol. Oceanogr. 1987, 32, 1277-1290.

14. Bonnet, M.P.; Barroux, G.; Martinez, J.M.; Seyler, F.; Moreira-Turcq, P.; Cochonneau, G.; Melack, J.M.; Boaventura, G.; Maurice-Bourgoin, L.; León, J.G.; Roux, E.; Calmant, S.; Kosuth, P.; Guyoth, J.L.; Seyler., P. Floodplain hydrology in an Amazon floodplain lake (Lago Grande de Curuai). J. Hydrol. 2008, 349, 18-30.

15. Takeuchi, K. Analyses of the flow regime of the Chao Phraya River. In Hydrology of Warm Humid Regions, Proceedings of the Yokohama Symposium, Yokohama, Japan, July 1993; International Association of Hydrological Sciences: Paris, France, 1993; Vol. 216, pp 181-193.

16. Chow, V.T.; Maidment, D.; Mays, L. Applied Hydrology. McGraw-Hill: New York, NY, USA, 1988 ; p. 572.

17. Shuttleworth, W.J. In Evaporation; Maidment, D.R., Ed. McGraw-Hill: New York, NY, USA, 1993; pp. 4.1-4.53.

18. LaBaugh, J.W.; Winter, T.C. The impact of uncertainties in hydrologic measurement on phosphorus budgets and empirical models for two Colorado reservoirs. Limnol. Oceanogr. 1984, 29, 322-339.

19. Krause, S.; Bronstert, A. An advanced approach for catchment delineation and water balance modelling within wetlands and floodplains. Adv. Geosci. 2005, 5, 1-5.

20. Jensen, M.E. Consumptive Use of Water and Irrigation Water Requirement. American Society of Civil Engineers: New York, NY, USA, 1973.

21. Chapra, S.C.; Canale, R.P. Numerical Methods for Engineers. McGraw-Hill Book Company: New York, NY, USA, 2002.

22. Madsen, H. Automatic Calibration and Uncertainty Assessment in Rainfall-Runoff Modelling. In Proceedings of Joint Conference on Water Resource Engineering and Water Resources Planning and Management 2000, Minneapolis, MN, USA, 30 July-2 August 2000; Hotchkiss, R.H., Glade, M., Eds.; ASCE: Reston, VA, USA; pp 1-10.

23. Krause, P.; Boyle, D.P.; Base, F. Comparison of different efficiency criteria for hydrological model Assessment. Adv. Geosci. 2005, 5, 89-97.

24. Vudhivanich, V.; Pajongkitkran, S.; Bunpian, A.; Cherdchanpipat, N. Irrigation Efficiency of the Greater Chao Phraya and the Greater Mae Klong Irrigation Projects. Kasetsart J.: Nat. Sci. 2002, 36, 110-118

25. Rosenberry, D.O.; Winter, T.C.; Buso, D.C.; Likens, G.E. Comparison of 15 evaporation models applied to a small mountain lake in the northeastern USA. J. Hydrol 2007, 340, 149-166.

26. Vadervas, M.; Fountoulakis, A., Estimation of lake evaporation from standard meteorological measurements: application to four Australian lakes in different climatic regions. Ecol. Model. 1996, 84, 139-150.

27. Vallet-Coulomb, C.; Legessea, D.; Gassea, F.; Travic, Y.; Chernet, T. Lake evaporation estimates in tropical Africa (Lake Ziway, Ethiopia). J. Hydrol. 2001, 245, 1-18. 
28. Rosenberry, D.O.; Stannard, D.I.; Winter, T.C.; Martinez, M.L. Comparison of 13 equations for determining evapotranspiration from a prairie wetland, Cottonwood Lake area, North Dakota, USA. Wetlands 2004, 24, 483-497.

29. Lesack, L. Seepage Exchange in an Amazon Floodplain Lake. Limnol. Oceanogr. 1995, 40, 598609.

30. Kingsford, R.T.; Jenkins, K.M.; Porter, J.L. Imposed Hydrological Stability On Lakes In Arid Australia And Effects On Waterbirds. Ecology 2004, 85, 2478-2492.

31. Halls, A.S.; Lieng, S.; Ngor, P.; Tun, P. New research reveals ecological insights into dai fishery. Catch and Culture, June 2008, pp. 8-12.

32. Sutcliffe, J.V.; Parks, Y.P. Comparative water balances of selected African wetlands. Hydrol. Sci. 1989, 34, 49-62.

33. Samma, A. Inland Fisheries Administration, Thai Department of Fisheries, Bangkok, Thailand. Personal Communication, 2005.

34. Thai Fisheries Department, Bangkok, Thailand. Personal Communication, 2006.

35. King, J.; Brown, C., Environmental flows: striking the balance between development and resource protection. Ecol. Society 2006, 11, 26.

\section{Appendices}

Rating curve information and staff gauge location.

\begin{tabular}{|c|c|c|c|c|c|c|c|c|c|c|}
\hline \multicolumn{6}{|c|}{ Inflow Rating Curve } & \multicolumn{5}{|c|}{ Outflow Type 1 Rating Curve } \\
\hline Location & Type & $\mathbf{n}$ & $\mathbf{Q}$ & $\boldsymbol{R}$ & Range & Type & $\mathbf{n}$ & $\mathbf{Q}$ & $\boldsymbol{R}$ & Range \\
\hline K. Bon† $\dagger$ & channel & 18 & $0.044 \mathrm{H}^{35}$ & 0.91 & $23.2-24.2$ & Pumped & 14 & $0.044 \mathrm{H}^{46}$ & 0.94 & $22.0-22.8$ \\
\hline K. Tatako & channel & 26 & $0.046 \mathrm{H}^{37}$ & 0.90 & $22.3-24.1$ & Pumped & 15 & $0.044 \mathrm{H}^{61}$ & 0.81 & $21.8-22.8$ \\
\hline K. Tatako & overbank & 13 & $0.043 \mathrm{H}^{41}$ & 0.90 & $24.2-25.0$ & NA & & & & \\
\hline Irrigation 1 & channel & 19 & $0.042 \mathrm{H}^{66}$ & 0.65 & $23.1-24.4$ & Pumped & 6 & $0.043 \mathrm{H}^{31}$ & 0.81 & $22.0-22.7$ \\
\hline Irrigation 2 & channel & 17 & $0.042 \mathrm{H}^{48}$ & 0.94 & $23.2-24.1$ & Pumped & 10 & $0.042 \mathrm{H}^{45}$ & 0.90 & $22.5-22.8$ \\
\hline Weir & NA & & & & NA & Gravity & 7 & $0.043 \mathrm{H}^{143}$ & 0.99 & NA \\
\hline Nan Regulator & NA & & & & NA & Gravity & 7 & $0.043 \mathrm{H}^{133}$ & 0.89 & NA \\
\hline
\end{tabular}

Note: $\mathrm{Q}$ is discharge in $\mathrm{m}^{3} \mathrm{~s}^{-1} ; \mathrm{H}$ is stage height in metres (MSL); $R$ is the correlation coefficient; and Range is the stage range of the flow measurements used to construct the curve. NA - not applicable.

$\dagger$ The inflow rating curve for $\mathrm{K}$. Bon was not calibrated for flows $>24.2 \mathrm{~m}$. Although these were rare, the error in the inflow estimates would be higher at that time. 
Volume of water represented by the measurement error in each component of the water budget over three complete water cycles.

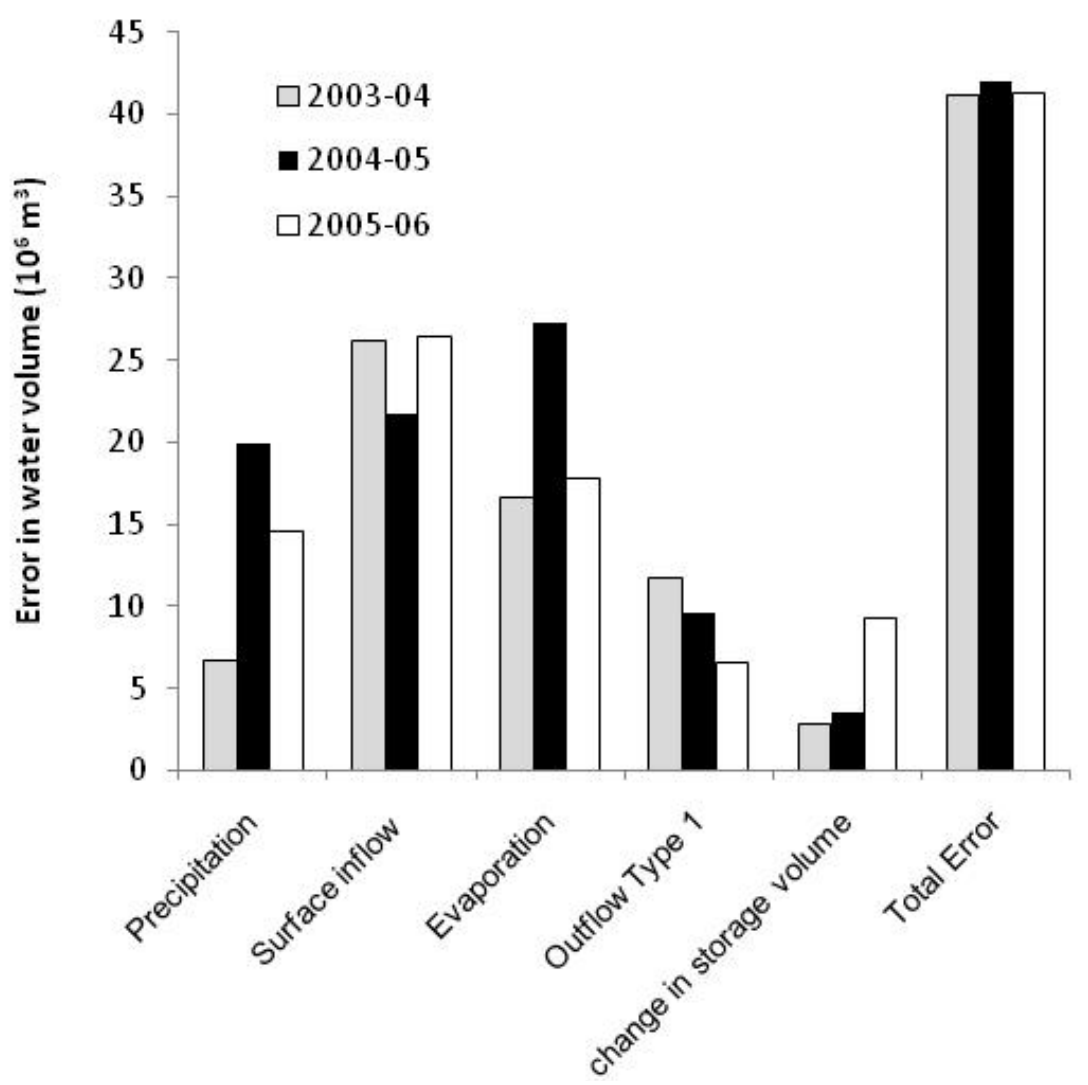

(C) 2009 by the authors; licensee Molecular Diversity Preservation International, Basel, Switzerland. This article is an open-access article distributed under the terms and conditions of the Creative Commons Attribution license (http://creativecommons.org/licenses/by/3.0/). 